\title{
The Implicit Impact of the Russian Governmental Governance
}

\author{
Taiyi Yang* \\ School of Economics and Management, Tongji University, Shanghai 201800, China \\ *Corresponding Author email: 15316701381@163.com
}

Keywords: Russian; power; government

\begin{abstract}
As the power in Russia is highly concentrated in hands of one certain group of people, only some high level of officials has the discretion on public expenditure while public have fewer power to against some actions of the public officials. As we all know the Russian government is not governed in an optimal way. In this chapter we will try and break this down through some concrete examples, in other words, how the Russian senior political officials uses their power in an unorthodox way to benefit themselves and secure their power at the expense of the population. Another clear example on how the Russian government protects their political standing is throughout the strict control of the Russian media. The whole Russian media is in other words under the government is payroll, which means that the government can control and manipulate everything that the Russian media broadcasts.
\end{abstract}

\section{Introduction}

During the past decade the Russian Federation has emerged from nothing to one of the world's most promising economies, rising from post-Soviet economic chaos to year-on-year growth, even during obstacles like the global financial crisis. However, although all of the short-term achievements, the country is still struggling with a high level of endemic corruption and governance difficulties that is restraining the Russian political and economic development, and threatens to affect the long-term performance of the country. (Julia Pettengill, 2013)

One of the major policy issues behind this is the governmental governance in Russia, that arose in the aftermath of the transition to a market economy. During the transition from an authoritarian state with a centralized economy to a capitalist democracy, the disruption of federal institutions made the country extremely vulnerable to corruption. During this sensitive period of time Russia was wounded by a lot of privatizations, industrial restructurings, foreign trade, and criminal activities, this led to a birth of Mobs and Oligarchs and has from that day on affected the level of instability in the Russian Federation. However, since Vladimir Putin rose to power in 2000, and became the president of the Russian Federation, he centralized the power and overtook the media from the Mob. This led to more bureaucracy and shifted corruption from a more criminal point of view to a (governmental corruption). Meaning that more and more sectors within the Russian government became worse governed and monitored. (Julia Pettengill, 2013)

According to Transparency International Russia ranked the 131 most corrupt country in the world out of 176 countries in 2016. In this paper we will with help of a PESL and four specific selected fields that can be used to rate the quality of an institution, analyse the implications, both internally and externally, that follows from the actions made by the government. The fields that we decided to analyse are, political stability, economic \& environment, social \& media, and control of corruption. Every analysis is narrowed down to, in our opinion, the most interesting and recent events. This because of the restricted number of pages we are allowed to write and the width of the subject.

\section{Corruption in Russia}

The quality and quantity of bureaucrats play an important role in the level of corruption in a country. The larger the size of a state, the more bureaucrats there are, the more opportunities for them 
to take bribes. In some major cities in Russia where many bureaucrats are concentrated have a higher corruption rate (Orttung $R$, 2006). As the power in Russia is highly concentrated in hands of one certain group of people (Alexandra K, 2012), only some high level of officials has the discretion on public expenditure while public have fewer power to against some actions of the public officials. As a result, the current bureaucracy in Russia has more opportunities to gain a benefit from bending or breaking the rules because of the centralization of the power and lack of controls. This situation is having a detrimental effect on the society and government. The imperfection of Russian regulations may also lead to bad governance in Russia. These regulations to some extent provide the officials the monopoly power in authorizing people to engage in many activities that need permits or licenses. Also, these government offices are inefficient, and it may take months to authorize the activities if you do not provide enough bribes. The fact that in some cases bribery is better and faster than legal ways in solving problems in business.

Lack of transparency in rules and the inadequacies of the current legal system limits the chances for public to control efficiently. Though Russia has acceded to the UN Convention against Corruption Preamble and promulgated several laws and regulations on anti-corruption, the formulation and implementation of these related laws and regulations remained sluggish. (Socialism Studies, 2007) So, the inadequacies of Russian legislation provide room for corruption. In addition, some laws and rules are unclear and confusing or even not publicly available, which can cause different interpretations of the law. Justice system is under the influence of those who have the political power and the judges themselves are engaged in acts of corruption and have political biases, which do not help to create a corruption-free society.

As in the process of privatization, government gains more benefits. While Russia takes over more assets, it is easy to form a monopoly power between government and business, which stimulates corruption in Russia. According to a report, bribery accounts for 30\% of the company's total spending (China Daily, 2013, February 5).

There is also a correlation between the level of public sector salaries and the level of engaging in bribery. The wages paid to civil servants are the main source of their income. If the level of public sector wages cannot reflect the effectiveness and fairness, it is more likely for corrupt transactions to take place. It seems that the best way to reduce this phenomenon is to increase the level of wages for public employees. However, some argue that there is no correlation between the level of wages and bribery. Although higher salaries can reduce temptation for them to be engaged in bribery in some degree, they will not provide enough to reduce it as some of the bribes offered illegally are way too large to resist.

Acts such as graft, embezzlement, extortion, taking bribes formed during the Soviet era still play an important role in the real life after the disintegration of the Soviet Union. And those new dignitaries still engage in bribery in their life. As a result, these phenomenon in the Soviet Union still exist in the political, social, economic life of Russia.

\section{Impact of the Government: Inside Effects}

As we all know the Russian government is not governed in an optimal way. The level of corruption is high, and the government holds the population on a tight string. Corruption is a phenomenon that is most effective when undiscovered. The use of corruption is when you use the rights of somebody else to benefit yourself. When you do this without nobody noticing it, you can achieve huge things, this is something that the senior officials and government in Russia do very well. $\mathrm{n}$ this chapter we will try and break this down through some concrete examples, in other words, how the Russian senior political officials uses their power in an unorthodox way to benefit themselves and secure their power at the expense of the population.

\subsection{Political Stability}

Let's start with a pretty recent example, The Russian invasion of the Crimea part of Ukraine. Why does a world leader prepare to risk possible economic decrease and international complications over a 
piece of land? The whole invasion has been estimated in a total cost for the Russian government of more than $\$ 70$ billion, without including the cost of the sanctions imposed by the west. So, what was the real interest in Crimea - a sort of island, connection to the Mediterranean, natural reassures of the black sea, or to protect ethnic Russians? People close to Putin enjoy vast wealth, but 20 percent of the population still lives below the poverty line, so clearly ordinary Russians are not his priority. Meanwhile, Russia's far-right party, the LDPR, has more seats in the Russian parliament than there are far-right seats politicians in Ukraine (euobserver, 2014).

So, what are the real interests of Putin and the Russian government? There are two reasons that are clearly connected to these actions, Black gold and fear of revolution.

During Putin's announcements on the Crimea crisis he told the media that the region was always a part of Russia in the people's heart of hearts. However, Russia doesn't seem to care about injustices against its own people, this is pretty easy to prove true so there was surely a different reason, which is oil and gas, since Crimea is rich in these natural resources. Yet, the most natural reason why Russia Putin entered Crimea is the fear of a Revolution. Andrey Zubov, a professor at the Moscow State institute of International Relations, told the Financial Times that Putin and Russian official are scared. The Moscow's rulers feared that the Ukraine's anti-communist spirit Maidan protest movements could replicate itself in Russia (Bustler, 2014)

Putin even revealed later that the Russian takeover of Crimea had been planned for a long time before the real actions and that he himself took the final decision about Crimea after secret undated opinion (BBC, 2015). A second example of the political instability in Russia are the links between organized crime, the state, and corruption which are deeply ingrained in Russia. According to WikiLeaks cable release in 2010, the Russian state security agencies is suspected of sponsoring organized crime to carry out criminal operations, and of providing protection to crime syndicates in turn (Pettengill, 2013).

\subsection{Social Media}

Another clear example on how the Russian government protects their political standing is throughout the strict control of the Russian media. Since Putin raised to the power in 2000 his first actions were centralization of the power and to introduce state propaganda instead of free media. The whole Russian media is in other words under the government's payroll, which means that the government can control and manipulate everything that the Russian media broadcasts. An average daily Russian newscast broadcast for 3 hours. Russian law even forbids foreign investors to own more than 20 percent of any media company in Russia. As an example of a Russian newscast is how everything is an "Americanised conspiracy", how Russia is surrounded by enemies, and that Putin is the only man that can protect Russia. In other words, Russian TV is a mix of propaganda, celebrations and brain washing reality shows.

Bad governance of institutions in Russia doesn't only affect the country on a macro level but also on a micro level. Corruption has showed to have impact on a lot of different sectors but a lot of these effects that rises from corruption is somewhat invincible for the untrained eye. Corruption has a huge impact on living standards in Russia and researches has shown that it, among other things, has a negative impact on reproduction of human capital and the sustainable development. (Absalyamov et al. 2016)

\subsection{Economy \& Environment}

In Russia money is still the number one priority for the majority of the population.

As we can see Putin has made himself and his companions some of the wealthiest people on this planet, I wild guess is that nobody exactly know how much their property is worth. So, how is this possible and how does it affect the people of Russia?

First of all, The Russian government has a monopolistic control over the gas industry, which means that they can do pretty much whatever they want with their baby Gazprom. Gazprom has been Putin's main preoccupation since 2001 (as we can connect to the Crimea crisis), but it has been a spectacular failure, at least for the populations of Russia. The company possesses huge natural 
resources (a quarter of global reserves of traditional gas), however, it is extremely inefficient because of poor management and massive corruption. In short, the way Gazprom is run is an accurate model of how Putin rules Russia. In 2001 Putin fired the CEO of Gazprom as an attempt to clean up this pervasively corrupt organization. However, the only significant structural reform was the liberalization of sales of Gazprom's stock which led to an increase of its stock prices in 2006. Since Putin rose to power Gazprom's management have been existing of three groups, CEO Alexei Miller's young St. Petersburg economists, a group of St. Petersburg KGB officers - both closely linked to Putin himself, and a third group of old Gazprom officials. Putin placed himself in a position that controlled so that none of these factions gain too much power; Putin thus retains the ultimate responsibility for the company. Gazprom is typically famous for their unproductive capital expenditures and unnecessary investment, which in other hand is money that disappears without nobody knowing where, and their asset stripping to different private sectors for exceptionally high prices (TheMoscowTimes, 2012).

The Russian government also have their nails in the Banking industry. A research done by the Bank of Finland shows that corruption on a highly level in Russia diminishes bank lending. Estimations by type of borrowers showed that corruption favours lending to government entities over lending to households and firms (Laurent Weill, 2008).

Thus, this is just two of the typical sections that are detrimental from the corrupted society within the Russian economy it is important to keep in mind these kinds of actions have negative externalities on other sections and mainly on the population of Russia. For example, a high level of corruption reduces the amount of foreign direct investments and lowers the Gross domestic product per capita, and don't forget about the impact on the environment. Because of the troubled international relationships that Russia has with drowned on themselves, sanctions and other problems have made Russia to survive on their reserves. As a result of this, Russia has had to make drastically moves in among else the oil industry. Without the real technology needed and environmental safety equipment, Russia has been extracting oil and gas from crucial locations like the artic. Because of this, a lot of Russian land area is heavily damaged by oil spills and other environmental unfriendly elements (Greenpeace, 2013).

\subsection{Control of Corruption}

As a we have mentioned many times throughout this chapter corruption has a large impact on how the Russian government is governed, Corruption is not new to Russia, nor is it unique, but, as Mark Galeotti explained "Russian corruption is unique in terms of the stage Russia is at in its global development." As much as corruption primarily impacts the Russian people, it also undermines the global economy, and devalues the rules of law and the rules-based financial system on which economic stability depends. Corruption has also been defined by Ana Eiras in 2003. Eiras defined corruption as a direct connection how the economic freedom in a country affects how much of the GDP the informal economy possesses. This is one of the main points that we are trying to lift forward in this paper, how the Russian government restricts the location in a way to benefit themselves.

Corruption significantly impedes business operations and investments in Russia. High-level and petty corruption is a common thing in most of the institutions governed by the government in Russia, especially in the judicial system and public procurement. The business environment continuously suffers from a lack accountability, transparency, and inconsistent application of law. Russia's regulatory inefficiency substantially increases the cost of doing business and effects the market competition in a negative way (Russian Corruption Report, 2017).

The Russian government have tried to restrict the level of corruption during the past years with different anti-corruption laws, for example, laws that requires companies to actively implement anti-corruption compliance programs. However, effective enforcement of anti-corruption legislation is burden by a politicized and corrupt judicial system. 


\section{Impact of the Government: External Effects}

\subsection{Political stability}

It's quite clear that the corruption in Russia affects domestic security but it has also got an effect on the international security. In the article Russian corruption: Domestic and international consequences"' published by Henry Jackson Society the links among corruption, organised crime and politics are explained and showed how they're nicely established in the country. According to WikiLeaks cables released in 2010; state security agencies in Russia are suspected of using organised crime to achieve criminal operations and of allowing protection to crime syndicates in turn. Further, it is mentioned how organised crime and politics are deeply interconnected in Russia. From an international aspect, and Russia being one of the biggest economies in the world, the corruption poses huge problems to the operation or handling of world affairs. The Russian organised crime is a major player in the drugs trade and human trafficking throughout Europe but also worldwide. The connections are everywhere, both the street level crime and white-collar crime. To start with, it is mentioned in the article "'The Russian Mafia and organised crime: how can this global force be tamed?' by openDemocracy, that in Western Europe street level crimes such as cigarette smuggling and human trafficking (prostitution) is controlled by the Russian organised crime operators, or simply put, the Russian mafia. Further, in Portugal and Spain they're involved in street level robbery, credit card theft and high-level money laundering. In other words, Russian organised crime is operated and connected multi-nationally. The corrupted connection between politics and the organised crime in Russia creates leeway and opportunities for crime networks in Russia operating worldwide.

The Russian government own the gas and oil sectors in the country. Gazprom owned by the Russian state and has the biggest gas reserve in the world, oil company Rosneft which also is owned by majority of the Russian state and the list goes on. Further, Russia stands for 30 per cent of Europe's oil use and 24 per cent of its natural gas (thebalance.com). It's fair to say that, because of the corruption and instability of the Russian government, for countries relying on Russia in providing gas and oil could be a threat or uncertainty.

The Russian government has over the years showed some interest in, and has been involved in, different disputes worldwide. There has sometimes been a quite clear interest in interfering other state's affairs from the Russian government. Most recent examples of this is the war in Ukraine, Crimea and in Syria as well as meddling in the elections of other nations. Moreover, an article from USA Today show that Russia has interfered in political affairs with more than 27 states in North America and Europe. These interferences vary, e.g. it involves everything from cyber-attacks, to money laundering in Madrid, and financing elections etc. These state affairs interferences haven't always been approved by countries and institutions involved and have therefore led to sanctions against at Russia, e.g. from the U.S. and EU. Of course, it's not only Russia who have interests abroad, the U.S is well-known for interfering widely in state affairs and politics worldwide. But it is the proceedings of the interference of the Russians that sometimes can be questioned.

Another problem internationally is Russia's brand image, or maybe better phrased the 'state", image and to be perfectly clear; Russia's international image. According to research done by the Pew Research Center, in which over 40000 respondents from 37 countries outside of Russia where questioned about opinions of Russia, when asked if opinions about Russia are negative or positive, views of Russia were quite negative. A global median showed $40 \%$ of the respondents having discouraging thoughts about Russia. And least sympathetic was the opinions from North America and Europe. Further, when asked if Russia disrespects personal freedoms of its people a global median of $46 \%$ thought Russia didn't. There is a very visible difference comparing the positive and negative views of more developed countries, with a more negative view, and the less ones with a slightly more positive (PewGlobal.org.) These international views of Russia are a sign of unstable relations between Russia and, primarily, western countries, which affects Russia's handling in all kinds of international affairs. 


\subsection{Economic and Environmental}

\subsubsection{Arms trade}

Russia is the second biggest exporter of weapons in the world (after the U.S.). Russia supports a wide range of regions in the world with arms, e.g., Asia accounting for $70 \%$ of the arms export and then The Middle East and North Africa as the second largest markets (Chathamhouse.org). Russia has been claimed to supply different troubled areas and war zones with arms when the West have said no. For example, this July Russia agreed on supplying Nigeria arms, more specifically aircrafts, to fight Boko Haram but they could also be used to fight Niger Delta militants in a war of oil. Nigeria also sought to buy from the U.S. but because of the poor human rights records in Nigeria it caused opposition among members of the congress (cfr.com). Further, this April a top U.S. general confirmed that Russia is supplying weapons to the Taliban in Afghanistan which would be a violation of international law (thewashingtonpost.com). By supporting weapons this freely around the world it might, and probably will, lead to ending up in the "wrong"' hands and supporting countries and different organisations with poor human rights regulation and jurisdiction.

\subsubsection{Gazprom}

It is well-known that Gazprom has violated environmental laws and regulations, exerted risky oil rig operations, and showed that they really don't care for the environment. Their oil rigs are old, unsafe and doesn't follow the standards. For example, in 2011 the Kolskaya oil rig capsized, claimed 53 people's lives but also polluting waters with big marine-life resources. The oil rig should have, according to regulations, been 20-kilometers offshore but, still, it was only 12-kilometers from the coastline. This is just one example amongst many and drilling oil in the arctic, as Gazprom does, is a very hazardous process which both Shell and BP have chosen not to do because of the risks (TheMosocwTimes.com). These oil spills have huge effect on the wildlife and the ecosystem in the surrounding waters as well as it takes a long time to recover from it. Another point to consider is that some large western companies also have cooperation or deals with Gazprom. For example, Gazprom and Shell have a global strategic alliance together. As well as E. ON and OMV are working with Gazprom building pipelines (Reuters.com). This could be viewed as a bit controversial because of the lack of environmental sustainability within Gazprom as a corporation. The cooperation could be regarded as Shell, and the others, accepting or just bypassing the fact that Gazprom's environmentally careless and not sustainable.

\subsubsection{Foreign investments}

Because of the high levels of corruption, political risk, and uncertainty in Russia it makes foreign investments in the country a risky and difficult business to handle. As earlier mentioned, corruption foremost impacts the Russian people, but it also weakens the global economy, the financial system and discredits the rule of law from which economic stability is derived. Corruption is therefore somewhat exported into the international market through the Russian businesses and banks which creates an instability and a lack of security on the international financial system (HenryJacksonSociety).

In the north west of Russia there're some Scandinavian companies who have invested but especially the smaller foreign firms that invest in Russia are exposed to local corruption. But these bad conditions concerning foreign investments in Russia are also unlikely to change (U.S. Department of State). An example is a Finnish windowmaker investing in Russia adopted a zero-tolerance policy to the local corruption. Every time someone walked up to them and asked for money they went to court with the case, it lead to 44 cases until they stopped asking them(cnbc.com). Furthermore, there's a lot of potential money to be earned for foreign companies on the Russian market, but of course to the cost of huge risks. The problem is understanding the terms of business in the Russian business environment (financialpost.com). A survey from EY consisting of foreign companies with investments in Russia show that $77 \%$ of foreign companies crave a more stable business environment on the Russian market. Further, about $90 \%$ of the answering companies 
portrayed the situation as demanding. Nonetheless, about $50 \%$ were still optimistic about future possibilities and would expand their business in the country (EY.com)

Due to the corruption-related issues, which undermines stability and security, the Russian market is not that lucrative for foreign investors. Because of the market environment being somewhat closed or difficult to operate in it leads to a slower economic development in the country.

\subsubsection{Social Media}

Vladimir Putin, maximum Russian exponent is a firm follower of the news not only nationally but also internationally. His philosophy is that who owns the media controls what they say. That is why since he came to power he did everything possible to obtain ownership of both state and privately-owned media. Due to their duties and obligations, he cannot follow them regularly and that is why the media channels make a summary therefore he can follow them without problems and be up to date.

Even not being an expert, he is also able to control the internet and social network and therefore know what happens instantly and be able to get involved. Within the country he has all media controlled whereas outside its borders he uses Russia Today to deny everything it is said about his country. (The Atlantic, 21th April 2015).

As an example of how Russia manipulates what happens externally through Russia Today, it is possible to mention the Dutch Referendum. At the beginning of April 2016, a referendum took place in the Netherlands in which the trade agreement between Ukraine and the European Union, whose goal is to liberalize trade between them, was questioned. The final result was voting against the treaty and it is believed that this negative vote has its origin in Russia. First of all, because many of the themes and headlines of the campaign in favour of it come from Sputnik, the Russian state propaganda website and from the Russia today. In addition, to encourage the voters to say no, it was stated that Ukraine was responsible for a plane crash, where Russian separatists shot down a plane over Ukraine two years earlier. (The Washington Post, $8^{\text {th }}$ April 2016).

In like manner, Russia also influenced the results of the U.S elections. Russia stole many emails from the Democrats and also used social networks to encourage disagreement and division among the American society by mentioning key topics such as race or gun rights. Immediately touched some other thorny issues such as white supremacy while involving NFL players,for example.The main objective was to attack the United States at its most vulnerable moment in order to take away some of its power in global governance.

The threat was greater than everyone expected even Barack Obama thought so himself. On Facebook, one of the most important social networks, there were numerous interactions between American voters and people posing as if they were part of them in order to reinforce or change the intentions of the voters. However, not only Russia was interposed through Facebook but also through blogs, Instagram, Google, YouTube and even Pokémon Go (The Guardian, 14 ${ }^{\text {th }}$ October 2017).

Moreover, in France, Russia financially supports the far - right National Front led by Marine Le Pen. Additionally, the opposition party in this case, blames Russia for trying to get much of their emails and trying to hack their systems countless times (The Telegraph, $6^{\text {th }}$ May 2017).

Finally, it is relevant to highlight the influence that Russia could have had in the realization of the Brexit. According to sources such as Facebook or The Times, innumerable Russia accounts made publications about the referendum as well as propagating the vote to leave compared to stay. Specifically, social bots were used to misinform people and ultimately influence their votes.

All of this is because Russia is very hurt and offended with the idea that Ukraine can join the West and thus grow as a nation. In the same way, Russia fears that it will become stronger and there may be reprisals, so it will do everything possible to bring it down.

\subsubsection{Control of Corruption}

It is well known that corrupt economies are not able to reach their peak due to the counterproductive effect of not having a free market. For example, as stated by the World Bank, countries with high levels of corruption receive an average income of one third compared to countries 
with low levels of corruption. Likewise, a high level of corruption implies an unequal distribution of wealth in the country in question. This can be shown with the Gini Index, which in this case is 37, 7 with 100 being the highest inequality. (World Bank, 2015).

One of the most common characteristics of countries with high levels of corruption is the reduced interest in investing in technological advances. This is because they already dominate the market in such an incredible way that they believe they are invincible. For instance, mention the case of Gazprom who is not interested in innovating, when the gas industry is revolutionizing in terms of other sources of procurement and distribution. That is why it has been found that its exports have declined sharply and that one of its main suppliers of gas, Turkmenistan has opted to supply China.

Russia depends extraordinarily on foreign aid. It is known the amount of exports that the country carries out, mainly related to the energy sector but the country also requires financial aid that comes from outside. In this way, characterizing itself as a country with a high level of corruption does not benefit Russia at all because its supporters, aware that this is one of their weaknesses will attack there. For example, from USA some sanctions have come such as blocking the export of certain goods and services or freezing the financing of development projects. From UE, it is important to be stated the vet of European operators to buy or sell bonds / shares issued by financial entities of which Russia owns at least $51 \%$ equity. It is true then that Russia does not want to go against the USA and the EU because it needs them to push forward its trade balance. While it is true that Russia has its own currency, and its Central Bank could make a strong issue of it, but that fact would lead to a devaluation of the currency which would imply the consequent inflation in the Russia market (El País, 2014).

It is convenient to mention more concrete examples of how corruption in Russia can prevail over what an international organization dictates. In a very recent trial, and perhaps one of the most relevant cases of political influence on the courts, the known leader of the opposition and potential presidential candidate for the 2018 elections, Alexei Navalny, was sentenced to five years in prison for embezzlement by a provincial court in Kirov. As a condemnation, they prevented him from running for national elections next year. This was not the first time that the charismatic politician was condemned because he was initially blamed in 2013 for embezzlement $(\$ 502,700)$ in lumber from the national owned company Kirovles. Nevertheless, he appealed the sentence and following a rule issued by the European Court of Human Rights that qualified his trial as an injustice. At the same time, the Russian Supreme Court annulled that conviction and sent him again to Kirov for a new trial.

\section{Conclusion}

As we can see throughout these examples presented in the text, the impacts of the Russian government extend much longer than simply on a national basis. Although the decisions might only be meant for an internal purpose, the aftermath affects a much broader spectrum. While corruption is common to all countries, even democratic ones, it is clear authoritarianism is both a product and an enabler of corruption in Russia. The way the institutions are managed from the top to the bottom is totally inefficient. The population suffers from bad management in both an economic environment as in a social, without even having the power to affect it, drastically said, they don't even notice it because of the state propaganda. A badly governed government doesn't only affect the nation's economic growth but also its innovation and technologic development. Further on, connections with the Russian government and corruption decreases greatly the political stability in Russia. The Russian government linked with organised crime, which operates worldwide with e.g. drug trade, human trafficking, and smuggling, makes the government's legitimacy and trustworthiness dysfunctional. Moreover, Russia conducts arms trade with countries that might not follow the same human rights standards of other, especially, western countries. Additionally, interference in other state's affairs for example in Ukraine and Syria has led to sanctions against Russia. Consequently, the unstable and insecure business environment and political landscape in Russia, foreign investments are not lucrative resulting in a slow economic development. The political instability in Russia has even laid their tracks on media outside of their own borders. Studies and researches has shown 
connections between a Russian involvement in foreign countries presidential elections, for example, in the U.S. as well as in France. Several Russian media stations, like Sputnik and Russia Today, has also discovered some meddling in the British, and the vote of the Dutch referendum. So, it can clearly bee seen that the highly level of corruption in Russia has affected the levels of inequalities, as shown by the Gini Index, and that as long as the government continues to govern in a way that benefits themselves, the people of Russia as well as the directly affected foreign countries will also suffer.

\section{References}

[1] Yakovlev A. Evolution of Corporate Governance in Russia: Governmental Policy vs Real Incentives of Economic Agents [J]. Post-Communist Economies, 2004, 16(4):387-403.

[2] Haney M, Freinkman L. What Affects the Russian Regional Governments Propensity to Subsidize?[J]. Policy Research Working Paper, 1999:1-41(41).

[3] Utyasheva L. Russian Federation: governments threaten freedom of association and assembly for LGBT organizations [J]. Hiv/aids Policy \& Law Review, 2007, 12(1):31-32.

[4] Gerasimova V, Vladimirova S, Krupa O, et al. LAND VALUE TAXATION FOR RUSSIAN LOCAL GOVERNMENTS: EVIDENCE FROM SARATOV OBLAST[C]// National Tax Association, 2005:372-379.

[5] Liman I. New Goals for Local Governments in Russia: Training to Develop Small Businesses [J]. Journal of Public Administration Education, 1997, 3(1):73-74.

[6] Kipchatova T. Information Policy of Local Governments in Russia [J]. Doshisha Studies in English, 2002, 74:29-45.

[7] Sommerfelt H, Bhan M K, Brahmadattan K N, et al. International Law. De Facto Governments. Russian Soviet as Party Defendant [J]. Harvard Law Review, 1922, 35(6):768-769.

[8] Gerasimova V, Vladimirova S, Krupa O, et al. LAND VALUE TAXATION FOR RUSSIAN LOCAL GOVERNMENTS: EVIDENCE FROM SARATOV OBLAST[J]. Social Science Electronic Publishing, 2013, 98:372-379.

[9] WonHoCho. A Study on the Fiscal Autonomy of Local Governments in Russia [J]. 2010, 26(2): 89-111.

[10] Corvington P A, Struyk R J. Russian Social Assistance Nonprofits as Potential Contractors to Local Governments [J]. Nonprofit Review, 2003, 2:63-72.

[11] Anonymous. Acts of Unrecognized Governments. Effect Given to Decrees of the Russian Soviet Government in American Courts [J]. Columbia Law Review, 1930, 30(2):226-231.

[12] Weinthal E. Comparative Environmental Regulation in the United States and Russia: Institutions, Flexible Instruments, and Governance - By Lada V. Kochtcheeva; Environmental Justice and Sustainability in the Former Soviet Union - Edited by Julian Agyeman and Yelena[J]. Review of Policy Research, 2011, 28(6):635-638. 